\title{
The Impact of FDI in South Sudan
}

\author{
Tamburo Michael Renzi \\ Department of Business Management, LIGS University, Honolulu, HI, USA \\ Email: mr.tamburo@gmail.com
}

How to cite this paper: Renzi, T. M. (2021). The Impact of FDI in South Sudan. Modern Economy, 12, 303-316. https://doi.org/10.4236/me.2021.122016

Received: January 6, 2021

Accepted: February 16, 2021

Published: February 19, 2021

Copyright $\odot 2021$ by author(s) and Scientific Research Publishing Inc. This work is licensed under the Creative Commons Attribution International License (CC BY 4.0).

http://creativecommons.org/licenses/by/4.0/

\begin{abstract}
The primary goal of this study was to establish the impacts that FDI has had on South Sudan. Based on the ethnography design, this study's data collection approach involved a review of secondary data. The location-based approach and the institutional FDI fitness theories are the models that underpin the study. The results of the study are enlightening and intriguing. In addition to establishing that South Sudan has been unable to fully leverage FDI, the study also determined that FDI has failed to improve South Sudan's economy and that poverty levels in the country remain high. Furthermore, it was observed that despite modest increases in FDI levels, the quality of life for the people of South Sudan is still low and the country continues to grapple with a long-running civil war that has claimed thousands of lives. The main policy implication of the study is that South Sudan needs to take steps to create a political, social, and economic environment that foreign investors will find to be appealing.
\end{abstract}

\section{Keywords}

South Sudan, FDI, Impacts, Economy, Politics, Violence, Poverty, Living Standards

\section{Introduction}

\subsection{Background}

The eradication of poverty is among the main goals that the international community strives to accomplish. Eliminating poverty by creating economic opportunities is among the sustainable development goals that the United Nations has identified as among its key priorities. As part of the efforts to tackle poverty, the globe has adopted several measures and interventions. Foreign direct investment (FDI) is among the tools used to deliver economic empowerment and growth. As Magombeyi and Odhiambo (2017) established, existing research evidence suggests that on the whole, FDI is an effective instrument for addressing poverty. 
Focusing on countries in sub-Saharan Africa, Anetor et al. (2020) also confirmed that the FDI initiatives implemented in this region had had a significant impact on African nations' economies.

South Sudan is among the countries that rely immensely on FDI. For example, according to the World Bank (n.d.), the amount of FDI flowing into the country in 2018 accounted for $4.355 \%$ of the Gross Domestic Product of South Sudan. For 2017, FDI made up just 2.348\% of the nation's economy. From these figures, it is clear that foreign investors do not find South Sudan to be an attractive investment destination. Therefore, as it's established, the weak private sector coupled with the ineffective governance means that South Sudan's need for FDI is urgent and dire. Since it achieved independence in 2011, the country has been plagued by such challenges as high poverty levels and a civil war that has left thousands dead. For example, in a report released by Guvele et al. (2012), it was noted that the poverty rate in South Sudan stands at $90 \%$. Other figures indicate that as many as half of the country's population lives in poverty (IFAD, 2013). According to the World Bank (2020), at least $82 \%$ of the people of South Sudan are impoverished. Whereas it is true that FDI will not necessarily resolve the political challenges and government corruption that continue to plague South Sudan, it certainly promises to enhance the country's economic condition. The problems that South Sudan faces extend beyond poverty. Ethnic violence, a dysfunctional political system, a healthcare structure that is in shambles and corruption are other hardships that the country continues to grapple with (Mutenyo, 2011). These challenges have left devastating impacts on the nation. For example, estimates indicate that since ethnic clashes broke out in 2013, as many as 50,000 lives have been lost with some experts placing the death toll as high as 383,000 (Council on Foreign Relations, 2020). 2.24 million people in the country have been forced out of their homes and forced to seek asylum in neighboring countries (Council on Foreign Relations, 2020). Moreover, the country's healthcare system is so strained that it is unable to attend to the medical needs of citizens. For example, according to the World Health Organization (WHO) (n.d.), the country's ratio of physician to citizens is 1:65574 with a majority of the healthcare professionals being unskilled and poorly trained. These challenges will only worsen in the coming years as the country is still struggling to end the civil war and establish an inclusive and effective government. FDI therefore offers South Sudan an opportunity to emerge from conflict and experience political and economic growth.

\subsection{FDI Definition}

Duce and Espana (2003) offered an insightful definition of FDI. According to these scholars, FDI refers to setting up business operations by nationals and firms from one country to another. For example, when an American firm establishes a presence in Kenya, the American company has undertaken FDI. FDI is fundamentally distinct from foreign aid. Whereas FDI is concerned with generating profits, foreign aid is generally intended to support foreign governments 
by financing social programs, infrastructure projects, and other undertakings (Selaya \& Sunesen, 2012). Furthermore, while private individuals and firms mostly carry out FDI, foreign aid is usually delivered by governments.

\subsection{Research Questions}

The main aim of this study is to establish the impact that FDI has had on South Sudan. To achieve this goal, the study gave particular attention to the following sub-questions:

1) What has the impact of FDI on poverty rates in South Sudan been?

2) How has FDI impacted the political and business environment in South Sudan?

3) How has FDI shaped governance in South Sudan?

\subsection{Research Hypothesis}

The primary hypothesis that guided the study is that on the whole, FDI has helped to reduce poverty levels in South Sudan. This prediction is based on the understanding that in general, FDI enables nations to effectively eradicate poverty (Magombeyi \& Odhiambo, 2017). It was also hypothesized that FDI has resulted in an improved political and business climate in South Sudan. For example, it was expected that the study would reveal that due to FDI, South Sudan has opened its economy further to foreign investors and that the government is now more accountable and strives to ensure political stability. Research shows that FDI generally bolsters governance and leads to the establishment of an atmosphere that allows firms to operate freely (Krifa-Schneider \& Matei, 2010). Lastly, the study hypothesized that FDI has enhanced governance processes and structures in South Sudan. Such studies as those by Kurecic and Kokotovic (2017) served as the basis for this hypothesis.

Above, it has been reported that thanks to improvements in governance, South Sudan has witnessed some FDI benefits. To further understand the impact of FDI, it is helpful to examine the relationship between governance and poverty, one of the metrics used to assess the effects of FDI. In general, experts agree that good governance as measured by such issues as the reliability of government service delivery, stability of public institutions, state involvement in welfare programs, and the implementation of economic policies that deliver growth for all citizens, is among the prerequisites for successful poverty eradication (Doumbia, 2020; Kefi et al., 2013). Given this link between governance and poverty reduction, it is reasonable to hypothesize that any drops in poverty levels in South Sudan are the result of governance reforms that the country's authorities have implemented. For example, it could be that the government is instituting measures to guarantee food security, create employment, and ensure the stability of state institutions. The aim of the present study is to shed light on whether, by leveraging the power of FDI, the South Sudan government has succeeded in lowering the prevalence of poverty. 


\section{Theoretical Background}

The impact of FDI on South Sudan has not received adequate attention from researchers as only a few studies examine the changes that the country has undergone due to FDI. In this chapter, light is shed on the findings that other researchers have obtained following their investigation into the FDI outcomes.

\section{Theoretical Underpinnings of Foreign Direct Investment}

A number of theories have been developed to explain the impact that foreign direct investment has on nations. One such theory is the location-based approach. The basic premise of this framework is that the social, economic, and political conditions in the host country are the main determinants of the level of FDI (Makoni, 2015). For example, according to this theory, in general, nations that are endowed with natural resources, adequate supply of competent labor, business-friendly government policy, robust physical infrastructure, and a large market tend to attract FDI (Makoni, 2015). For the most part, this theory holds true. As the following discussion reveals, the factors that the location-based approach identifies have been shown to be among the key drivers of FDI.

Various factors have been shown to influence the impact of FDI. Asongu et al. (2018) shed light on some of these factors. According to these researchers, the political climate is among the primary forces determining whether FDI allows countries to achieve economic growth. For example, Asongu et al. (2018) established that in order for nations to experience the full benefit of FDI, they must create a political environment where businesses can operate freely and competitively. Furthermore, Asongu et al. (2018) noted that political stability bolsters investor confidence, thereby magnifying FDI's positive impacts. Asiamah et al. (2019) also noted that the political economy heavily shapes the effect of FDI. Using Ghana as a case study, Asiamah et al. (2019) observed that developing nations where peace and harmony prevail are better positioned to benefit from FDI than unstable countries that tend to frighten and worry foreign investors. Therefore, if they are to exploit FDI for their growth fully, developing nations must begin by establishing a political atmosphere that facilitates business.

Apart from political stability, FDI is understood to thrive in countries with friendly tax policies, competent and skilled workers, and robust infrastructure. As part of their discussion, Asongu et al. (2018) identified these as among the fundamental building blocks of effective FDI. For instance, according to Asongu et al. (2018), before committing finances to particular projects, investors require assurances that they will be entering a market with low tax rates and incentives as well as access to a large pool of well-trained and capable workers. Asongu et al. (2018) note that the labor force's quality sets apart countries that have managed to grow through FDI and those that continue to wallow in poverty and disappointing economic growth. Thus, to ensure that FDI empowers their people and allows them to escape poverty, countries should spare no expense in training their workers while investing in infrastructure projects. 
Institutional FDI fitness theory is yet another model that identifies the determinants of FDI levels and impacts. At the center of this theory is the belief that in order to attract and benefit from FDI, firms need to develop four essential pillars: effective government, a strong and free market, investment in education, and socio-cultural norms that promote investment (Makoni, 2015; Karau \& Mburu, 2016). Unlike the location-based approach which places emphasis on physical resources, the institutional FDI fitness theory insists that institutional factors like government policy, educational programs, and cultural norms are some of the key determinants of FDI. Usually, when countries are governed by authorities that support businesses and prioritize education for their citizens, FDI levels are high (Miningou \& Tapsoba, 2017). On the other hand, foreign investors tend to avoid nations plagued by illiteracy, hostile cultural practices, and corrupt and ineffective governance. Moreover, such nations are often unable to harness the full power of FDI (Omodero, 2019).

\section{Methods and Findings}

The chapter offers an overview of the methodology adopted for the study and the findings that the research yielded.

\subsection{Research Design}

The ethnographic design was adopted for the present study. Essentially, this design is concerned with examining the lives of a particular community through the lens of culture (Eriksson \& Kovalainen, 2008). Essentially, this approach involves exploring how such issues as cultural norms, rituals and habits influence how a specific group interacts within itself and with other populations. This design was deemed appropriate because it promised to highlight how the domestic environment in South Sudan has shaped its interactions with the rest of the world through FDI.

\subsection{Data Collection and Analysis Procedures}

For data collection, secondary data (desk research) is the primary method that was used. Essentially, desk research is concerned with the examination of existing data. For example, for this study, data published by researchers, media outlets, and organizations involved in policy formulation was considered. Desk research was appropriate for various reasons. Firstly, carrying out primary research would have been a daunting and arduous undertaking requiring massive levels of time and resource commitments. The choice of the secondary data collection methods raises questions about the reliability and validity of the study. It should be noted that tremendous caution was exercised to ensure that the study is both valid and reliable. Only recent, relevant sources published in peer-reviewed journal articles and by reputable organizations were considered for review. To be included in the review, it was required that all articles must have been published no earlier than 2010. The purpose of this condition was to ensure that all the ar- 
ticles offered relevant and updated information on the situation in South Sudan and the impact that FDI continues to have on the country. Among the reputable organizations that served as the sources for these articles include the International Fund for Agricultural Development, the Council on Foreign Relations, the World Bank, and the Brookings Institution. What makes these institutions credible is that they are reputed for their opinions on various global issues. For example, the World Bank is involved in various programs designed to improve the economic conditions in developing countries. For this reason, this organization is properly positioned to shed light on whether South Sudan has benefited from FDI. On the other hand, the Brookings Institution routinely authors articles that explore a wide range of social, political, and economic questions. In general, all the organizations whose publications were reviewed have a reputation for accuracy and objectivity. Secondly and most importantly, desk research facilitated the collation of insights from the existing research literature to determine FDI's net effect on South Sudan.

For data analysis, the thematic analysis method was used. This approach is a popular instrument that researchers use to identify the over-arching themes and messages emerging from literature (Castleberry \& Nolen, 2018). Essentially, following an extensive review of literature, the key messages and common themes were noted. The location-based approach and the institutional FDI fitness theory were used to narrow down the theory. For example, using the location-based approach, it was possible to focus on the main factors that are known to influence the impact of FDI.

\subsection{Results}

Summarized in the following sections are some of the findings that were obtained following the desk research.

\subsubsection{State of FDI in South Sudan}

Among the insights that emerged from the review of literature is that South Sudan has not received much FDI. According to Ragoussis and Shams (2018), in 2015, much of the finances that South Sudan received from foreign sources was in the form of aid. The Global Impact Investing Network (2015) also determined that South Sudan has some of the lowest levels of FDI compared to other developing countries. The data shared by this organization shows that South Sudan relies mostly on foreign aid that is provided by such countries as the United States and that the little FDI has mostly occurred in the oil industry. Petroleum companies based in countries like China, India, and Malaysia are among the few in South Sudan (Global Impact Investing Network, 2015). The depressed degree of FDI in South Sudan indicates that this nation's conditions are not ripe for foreign investment.

\subsubsection{FDI and Poverty in South Sudan}

There is no indication that FDI has helped South Sudan to tackle poverty. The 
scant available evidence suggests that despite significant increases in FDI, the rate of poverty in South Sudan remains stubbornly high. For example, figures show that between 2017 and 2018, the amount of FDI inflow into South Sudan increased from $\$ 1$ million to $\$ 60$ million. For the 2018-2019 period, data on the poverty rate in the country appears unavailable. This is not surprising given that the country is rocked by violence and instability that must be frustrating data collection efforts. In fact, in its own report of South Sudan's preparedness to combat climate change, the most recent data that the South Sudanese government issued was for 2016 when the poverty rate stood at $64 \%$ (Republic of South Sudan, 2018). However, even without this data, it is possible to make informed guesses about poverty trends in the country. For example, as noted earlier, the civil war in South Sudan persists. With this conflict, the authorities in the country are undoubtedly unable to invest in such programs for poverty eradication as employment creation. Therefore, one can conclude that despite the significant increase in FDI, poverty rates in the nation are still high. By 2019, the FDI level had dropped to a meager $\$ 18$ million (Societe Generale, n.d.). Poverty remains endemic in South Sudan. Siddig et al. (2013) are among the scholars who have highlighted the plight of poverty in the country and how South Sudan's authorities' desperate efforts have proven ineffective. Given that the FDI has failed to trigger a drop in poverty prevalence, it is fair to conclude that for South Sudan, at present, FDI is not an appropriately impactful solution to the poverty problem.

\subsubsection{Impact on Political and Business Climate}

In addition to failing to help South Sudan reduce poverty, FDI has also had no meaningful impact on its political and business climate. As noted above, in 2018, the country witnessed a significant increase in FDI inflow. One would expect that the more significant FDI would result in the improvement of political and business conditions. Unfortunately, as the US State Department (2018) observed, the political and business situation in South Sudan remains unconducive for investment. According to the State Department, South Sudan is still plagued by bloody civil war, and the country's authorities seem unable to establish a secure environment for attracting investors. The situation in South Sudan illustrates that FDI is not sufficient to promote political stability and the implementation of business-friendly policies. Instead, countries must first craft a business and political climate that boosts investor confidence.

\subsubsection{Standards of Living and Quality of Life}

In general, FDI has been shown to bolster economies and facilitate employment opportunities, thereby contributing to improvements in living standards. Despite having experienced some level of FDI, South Sudan has been unable to enhance its people's lives. As part of its report on the outcomes of FDI in South Sudan, the Global Impact Investing Network (2015) explicitly states that the FDI has delivered no enhancements in living standards. According to this organization, South Sudan's healthcare system is so broken and ineffective that the coun- 
try has the $7^{\text {th }}$ highest maternal mortality rate in the world. In addition to low standards of living, South Sudan is also confronted with a severe unemployment crisis. Akashraj and Atem (2020) established that at least 12.6\% of South Sudan's workforce is not actively engaged in any form of employment. This figure is relatively low, and it is reasonable to believe that the actual rate of unemployment is much higher. According to Akashraj and Atem (2020), youth and women bear the brunt of the unemployment challenge in South Sudan. Given the persistence of unemployment, there is no question that FDI has not led to any noticeable improvement in the quality of life for South Sudan people.

Further evidence that FDI has not resulted in a better quality of life can be seen in South Sudan's global ranking about happiness. In the 2019 edition of the World Happiness Report, South Sudan occupied the lowest position (France 24, 2019). Essentially, the report identified the people of South Sudan as the least happy in the world. Developed by the United Nations, the report considers such measures of living standards as life expectancy, freedom, corruption, social support, and generosity. South Sudan's poor performance indicates that the life expectancy is low, the country has an endemic corruption problem, its citizens do not enjoy freedom, and social support systems are weak. No amount of FDI could help South Sudan eliminate the numerous hardships that its people continue to face. However, South Sudan's bottom ranking clearly shows that FDI does not have the intended outcome of enhancing living standards.

\subsubsection{Impact on Governance}

Governance is yet another metric that can be used to evaluate the impact and effectiveness of FDI. Ideally, FDI should persuade authorities to adopt governance processes and systems that promote business activity and contribute to better living standards. Power struggles are among the problems that have made it difficult for South Sudan to establish stable and robust governance frameworks. For years, the country's current President Salva Kiir has been involved in a deadly battle against Riek Machar to control the country. Despite neighboring countries' efforts to broker peace between the warring factions, fighting persists in South Sudan (UN, 2020). The state of affairs in South Sudan demonstrates that unless accompanied by economic reforms and structural changes, FDI cannot deliver any significant governance benefits. When FDI is pursued in an environment where appropriate systems are lacking, investors will undoubtedly lose confidence. For example, as the African Development Bank Group (n.d.) established, some foreign firms that had set up operations in South Sudan have exited this market due to poor governance and political instability. FDI is expected to impose pressure on the government of South Sudan to introduce governance reforms. Instead, the country remains dysfunctional and unattractive to foreign investors.

\subsubsection{Negative Outcomes of FDI}

The discussion above has revealed that FDI has not improved the situation in South Sudan. Evidence suggests that in addition to failing to enhance the coun- 
try's economy, FDI has worsened its problems. For example, South Sudan's high corruption levels have partly been attributed to FDI (Gramer, 2019). Foreign investors face accusations that they have colluded with warlords and corrupt government officials to establish a culture of impunity and violence in the country. For example, it is alleged that Americans are involved in illegal arms trading, and oil companies are exploiting South Sudan's wealth at the expense of the country's growth and the future of its people (Gramer, 2019).

Furthermore, as Gramer (2019) revealed, foreign governments are involved in a complex web of corruption that thrives on South Sudan's instability and ineffective government. For example, the President of South Sudan is alleged to have colluded with foreign actors to take over and loot public institutions. Dar Petroleum, a petrochemical company with owners from such countries as China and Malaysia, also faces accusations of exploiting South Sudan's wealth (The Sentry, 2019). Deng Ngor Deng, a senior official in South Sudan's government, is believed to have ties to foreign nationals who are indirectly funding violence and the use of child soldiers. The daughter of South Sudan's president is also implicated in a scandal involving Chinese miners contributing to the displacement of thousands of people in the country (The Sentry, 2019). While most South Sudanese individuals continue to wallow in poverty, the country's political elite and unscrupulous business people are amassing obscene amounts of wealth, much of which is held offshore. The economic inequalities that remain pervasive in South Sudan are undoubtedly a product of FDI. Instead of enabling South Sudan to recover from years of conflict and poverty, FDI appears to be fueling conflict and sabotaging the country's progress.

\section{Discussion}

The assessment of the impact of FDI in South Sudan revealed some critical observations. First, data on the situation in South Sudan is scant. There appears to be no study that has been conducted with the express goal of establishing how FDI has influenced South Sudan. Secondly, while it has not offered South Sudan any clear or significant benefits, FDI has caused severe harm to the country. For example, as noted above, the corruption and violence that ails South Sudan have been blamed on FDI.

There is a need to investigate why South Sudan has been unable to join the growing list of countries where FDI's overall effect has been positive. The stubbornly persistent civil war is certainly one factor that has robbed South Sudan of the benefits of FDI. Researchers are united in insisting that political stability and peace are necessary ingredients for effective FDI (Haksoon, 2010; Kurecic \& Kokotovic, 2017). Until the government of South Sudan guarantees harmony and an end to the violence that has rocked the country, the benefits of FDI shall remain elusive.

As a republic, South Sudan is only nine years old as it achieved independence in 2011. Given the country's young age, it can be argued that it has not had enough time to experience FDI's positive influences. It is understood that the 
benefits of FDI are not immediate and that countries must be patient to witness the gains that FDI promises (The Economist, 2011; Lin \& Wang, 2017). One can argue that South Sudan has to wait before its economy improves. The standard of living of its people becomes better, and the problems plaguing the political and business climates are eliminated. Another assertion that one can make is that no amount of patience will generate the benefits South Sudan hopes to experience. The country's atmosphere merely is such that it scares away investors and denies the people of South Sudan the opportunity to escape poverty.

A better understanding of why South Sudan remains low and unstable despite FDI can be gained by examining the ease of doing business in the country. South Sudan ranks poorly regarding how well it supports foreign investors. For example, in addition to having some of the worst government corruption levels, the country is regarded poorly in terms of how easy investors can do business (Michigan State University, n.d.). Furthermore, South Sudan has failed to guarantee press freedom, and its taxation processes are investor-unfriendly. Moreover, the very structure of the economy of South Sudan makes it difficult for the country to take advantage of FDI. For example, in addition to having a short supply of qualified and competent labor, South Sudan's government does not invest adequate amounts in infrastructure projects (IGAD, n.d.). The unfavorable business environment leads one to conclude that the ineffectiveness of FDI results from domestic problems.

The authorities in South Sudan appear to understand that the business climate is not conducive to foreign investment as presently constituted. For example, in collaboration with the World Bank, the government of South Sudan recently adopted a plan to introduce legislative reforms designed to streamline the business registration process (IFC, n.d.). The government's changes serve as an indication that it is committed to establishing an atmosphere that attracts investors. Additionally, as part of its broader plan of promoting FDI, South Sudan joined the East African Community in 2016 (Haas, 2016). As a member of this economic bloc, South Sudan will gain access to a broader market and persuade investors to prepare for business. If the country stays on this path of progress, it can be expected to achieve lasting peace and attract more foreign investors.

\section{Conclusion}

The goal of the present study was to establish how FDI has impacted South Sudan. This objective has indeed been accomplished. The study has shown that the effects of FDI are not straightforward. For example, given the low levels of FDI, it is difficult to determine with certainty how the poverty rate, standards of living, and government have been affected by FDI. However, from the little available data, it has been confirmed that South Sudan has not benefited from FDI. If anything, the country has suffered as a result of foreign investments. In addition to entrenching corruption, FDI has also fanned violence in the country.

One of the limitations of the study is that it relied primarily on a limited 
amount of data. This shortcoming is a reflection of the fact that South Sudan has not been extensively researched. This study appears to be one of a few research efforts to shed light on how South Sudan has responded to FDI. There is no question that further research is needed. In particular, researchers need to seek to determine if FDI is responsible for the problems that South Sudan has been unable to resolve. Another explanation for the limited availability of data is that South Sudan remains war-torn. As a result, it is nearly impossible for the country's government or external actors to collect data. This problem highlights the role that political factors play in research. Without stability and peace, researchers are unable to perform their mandate as they struggle to obtain credible and reliable data.

There is no doubt that South Sudan authorities need to take urgent measures to rescue the country. The ongoing civil war, endemic poverty, low living standards, and inadequate infrastructure highlight the need for necessary reforms. A call is hereby issued to the South Sudanese government to act resolutely to end the violence and seek closer trade ties with the international community. Only when the government improves the business atmosphere will foreign investors be convinced that it is safe and profitable to set up operations in South Sudan.

This study has significant policy implications for South Sudan and other war-ravaged and poverty-stricken nations that are struggling to attract foreign investors. The study has demonstrated that for these nations to flourish, they must spare no expense in guaranteeing political stability and implement business-friendly policies. It is also critical for these countries to invest in education and actively reach out to investors. Moreover, these countries need to establish strong institutions that help to assure investors that their business interests will be safeguarded. With these measures in place, the nations can expect to reap the full benefits of FDI.

\section{Conflicts of Interest}

The author declares no conflicts of interest regarding the publication of this paper.

\section{References}

African Development Bank Group (n.d.). South Sudan. https://www.afdb.org/en/topics-and-sectors/initiatives-partnerships/fragility-resilience /promoting-private-investment-in-transition-countries/the-horn-of-africa-opportunity /country-profiles/south-sudan

Akashraj, D. P., \& Atem, K. K. G. (2020). An Overview of the Challenges of Unemployment in South Sudan, Theoretical and Empirical Review. International Journal of Research and Review, 7, 57-66.

Anetor, F. O., Esho, E., Verhoef, G., \& Nsiah, C. (2020). The Impact of Foreign Direct Investment, Foreign Aid, and Trade on Poverty Reduction: Evidence from Sub-Saharan African Countries. Cogent Economics \& Finance, 8, Article ID: 1737347. https://doi.org/10.1080/23322039.2020.1737347

Asiamah, M., Ofori, D., \& Afful, J. (2019). Analysis of the Determinants of Foreign Direct 
Investment in Ghana. Journal of Asian Business and Economic Studies, 26, 56-75. https://doi.org/10.1108/JABES-08-2018-0057

Asongu, S., Akpan, U. S., \& Isihak, S. R. (2018). Determinants of Foreign Direct Investment in Fast-Growing Economies: Evidence from the BRICS and MINT Countries. Financial Innovation, 4, Article No. 26. https://doi.org/10.1186/s40854-018-0114-0

Castleberry, A., \& Nolen, A. (2018). Thematic Analysis of Qualitative Research Data: Is It as Easy as It Sounds? Currents in Pharmacy Teaching and Learning, 10, 807-815. https://doi.org/10.1016/j.cptl.2018.03.019

Council on Foreign Relations (2020). Civil War in South Sudan. https://www.cfr.org/global-conflict-tracker/conflict/civil-war-south-sudan

Doumbia, D. (2020). The Role of Good Governance in Fostering Pro-Poor and Inclusive Growth. Washington DC: Brookings Institution.

Duce, M., \& Espana, B. (2003). Definitions of Foreign Direct Investment (FDI): A Methodological Note. Basel: Bank for International Settlements. https://www.bis.org/publ/cgfs22bde3.pdf

Eriksson, P., \& Kovalainen, A. (2008). Qualitative Methods in Business Research. London: SAGE. https://doi.org/10.4135/9780857028044

France 24 (2019). Finland Tops World Happiness Rankings, South Sudan Bottom: UN. https://www.france24.com/en/20190320-finland-tops-world-happiness-rankings-south -sudan-bottom-un

Global Impact Investing Network (2015). The Landscape for Impact Investing in East Africa.

https://thegiin.org/assets/documents/pub/East\%20Africa\%20Landscape\%20Study/11So uthSudan_GIIN_eastafrica_DIGITAL.pdf

Gramer, R. (2019). Foreign Investors Fueled Violence and Corruption in South Sudan. Foreign Policy.

Guvele, C., Faki, H., Nur, E., Abdelfattah, A., \& Aw-Hassan, A. (2012). Poverty Assessment in South Sudan. ICARDA.

Haas, A. (2016). What South Sudan Will Gain from Joining the East African Community. London: International Growth Center.

https://www.theigc.org/blog/what-south-sudan-will-gain-from-joining-the-east-african -community

Haksoon, K. (2010). Political Stability and Foreign Direct Investment. International Journal of Economics and Finance, 2, 59-71. https://doi.org/10.5539/ijef.v2n3p59

Intergovernmental Authority on Development (IGAD) (n.d.). Major Challenges Facing the South Sudan Economy.

https://land.igad.int/index.php/documents-1/countries/south-sudan/investment-5/100 9-major-challenges-facing-the-south-sudan-economy/file

International Finance Corporation (IFC) (n.d.). Rebuilding the Economy of South Sudan. https://www.ifc.org/wps/wcm/connect/news_ext_content/ifc_external_corporate_site/ news+and+events/news/southern_sudan_main

International Fund for Agricultural Development (IFAD) (2013). Enabling Poor Rural People to Overcome Poverty in South Sudan.

https://www.ifad.org/documents/38714170/39972426/south_sudan.pdf/d247b0b7-fc4f$4 \mathrm{e} 2 \mathrm{c}-\mathrm{a} 636-8 \mathrm{ac} 91 \mathrm{e} 66 \mathrm{bfbb}$

Karau, J. N., \& Mburu, T. K. (2016). Institutional, Governance and Economic Factors Influencing Foreign Direct Investment Inflows in East Africa. Journal of Economics and Development Studies, 4, 87-98. 
Kefi, M. K., Hadhek, Z., \& Adel, B. H. (2013). Poverty, Governance and Economic Growth. Journal of Governance and Regulation, 2, 19-24.

https://doi.org/10.22495/jgr_v2_i3_p3

Krifa-Schneider, H., \& Matei, I. (2010). Business Climate, Political Risk and FDI in Developing Countries: Evidence from Panel Data. International Journal of Economics and Finance, 2, 54-65. https://doi.org/10.5539/ijef.v2n5p54

Kurecic, P., \& Kokotovic, F. (2017). The Relevance of Political Stability on FDI: A VAR Analysis and ARDL Models for Selected Small, Developed, and Instability Threatened Economies. Economies, 5, 22. https://doi.org/10.3390/economies5030022

Lin, J., \& Wang, Y. (2017). The New Structural Economics: Patient Capital as a Comparative Advantage. Journal of Infrastructure Policy and Development, 1, 4. https://doi.org/10.24294/jipd.v1i1.28

Magombeyi, M. T., \& Odhiambo, N. (2017). Foreign Direct Investment and Poverty Reduction. Comparative Economic Research, 20, 73-89. https://doi.org/10.1515/cer-2017-0013

Makoni, P. L. (2015). An Extensive Exploration of Theories of Foreign Direct Investment. Risk Governance \& Control: Financial Markets \& Institutions, 5, 77-83. https://doi.org/10.22495/rgcv5i2c1art1

Michigan State University (n.d.). South Sudan: Indices. https://globaledge.msu.edu/countries/south-sudan/indices

Miningou, E. W., \& Tapsoba, S. J. (2017). Education Systems and Foreign Direct Investment: Does External Efficiency Matter? Washington DC: International Monetary Fund. https://www.imf.org/ /media/Files/Publications/WP/2017/wp1779.ashx

Mutenyo, J. (2011). South Sudan: Time to Focus on Challenges. Washington DC: Brookings Institution.

Omodero, C. O. (2019). Effect of Corruption on Foreign Direct Investment Inflows in Nigeria. Studia Universitatis Economics Series, 29, 54-66. https://doi.org/10.2478/sues-2019-0008

Ragoussis, A., \& Shams, H. (2018). FDI in Fragile and Conflict-Affected Situations. Washington DC: World Bank. http://pubdocs.worldbank.org/en/874311508856697692/GICR-05.pdf

Republic of South Sudan (2018). Initial National Communication to the United Nations Framework Convention on Climate Change. https://unfccc.int/sites/default/files/resource/South\%20Sudan\%20INC.pdf

Selaya, P., \& Sunesen, E. R. (2012). Does Foreign Aid Increase Foreign Direct Investment? World Development, 40, 2155-2176. https://doi.org/10.1016/j.worlddev.2012.06.001

Siddig, K., Ahmed, A., Jaafar, S., \& Salih, A. (2013). The Prevalence of Poverty and Inequality in South Sudan: The Case of Renk County.

Societe Generale (n.d.). Economic Indicators of South Sudan: Investment. https://import-export.societegenerale.fr/en/country/south-sudan/investment-indicators

The Economist (2011). For Investors, Patience Is a Necessity. https://www.economist.com/free-exchange/2011/07/01/for-investors-patience-is-a-nec essity

The Sentry (2019). The Taking of South Sudan. https://cdn.thesentry.org/wp-content/uploads/2019/09/TakingOfSouthSudan-Sept2019 -TheSentry.pdf

United Nations, UN (2020). South Sudan: Progress on Peace Agreement "Limps Along", UN Envoy Tells Security Council. https://news.un.org/en/story/2020/09/1072502 
US State Department (2018). 2018 Investment Climate Statements: South Sudan. https://www.state.gov/reports/2018-investment-climate-statements/south-sudan

World Bank (2020). The World Bank in South Sudan. https://www.worldbank.org/en/country/southsudan/overview

World Bank (n.d.). Foreign Direct Investment, Net Inflows (\% of GDP) Sudan. https://data.worldbank.org/indicator/BX.KLT.DINV.WD.GD.ZS?locations=SD

World Health Organization (WHO) (n.d.). South Sudan. https://www.who.int/workforcealliance/countries/ssd/en 